\title{
The Impact of Pandemic Dynamics in Differential Calculus Course: An Overview of Students' Self- Regulated Learning Based on Motivation
}

\author{
Kurnia Dirgantoro, ${ }^{1, *}$ Robert Soesanto ${ }^{2}$
}

\author{
1,2 Universitas Pelita Harapan \\ ${ }^{*}$ Corresponding author. Email: kurnia.dirgantoro@uph.edu
}

\begin{abstract}
During pandemic, learning has transitioned into online learning. This causes Universitas Pelita Harapan (UPH) students in Faculty of Education must be repatriated to their regions and undergo half semester of differential calculus learning in online mode. Therefore, it makes aspects of self-regulated learning (SRL) and motivation are important to be highlighted. Focus of this research is to see how SRL is formed as a result of learning transitions based on their motivations. The research samples use students from Mathematics, Physics, and Chemistry Education study programs who undergo an online learning transition. Likert scale questionnaires are used as instruments related to motivation and SRL. The research uses mixed methods approach which is analysed quantitatively and qualitatively. It shows that there is no difference in students' SRL from Mathematics and non-Mathematics Education study programs based on their motivations and there is no interaction between the study program and motivation in determining SRL. Quantitative results are strengthened by descriptive qualitative exposure through indicator and open-ended questions analysis on SRL instrument. The conclusion shows that students in Mathematics and non-Mathematics Education, both from high and low motivation groups, feel the need to develop their SRL during difficult situations in interpreting differential calculus learning provided by lecturers.
\end{abstract}

Keywords: online learning, self-regulated learning, motivation, differential calculus, pandemic.

\section{INTRODUCTION}

Today, the world society is faced with a covid-19 pandemic that causes in all structures and aspects of life undergoing a massive transition. The World Health Organization (WHO) noted that covid-19 was declared a global emergency by the end of January 2020 as well as a pandemic on March 11, 2020 [1]. One of the aspects affected by the pandemic is the educational aspect related to learning that occurs in both schools and universities. It shows where the whole learning process goes from face-to-face implementation to autonomous implementation from home [2]. Activities designed for students are also designed in such a way as to continue to accommodate the learning objectives that have been structured. Based on the phenomena, there is an online learning design that is considered appropriate in facilitating students' learning needs nowadays.

Specifically, in the context of university, online learning is defined as a synchronous and asynchronous learning experience using electronic devices accompanied by internet access, where synchronous focuses on real-time activities between lecturers and students, while asynchronous on free-time learning ([3], [4]). This online learning certainly gives a new atmosphere for students who tend to experience lectures face-to-face before the pandemic occurs. The argument from [5] states that online learning benefits students in developing entrepreneurial competencies, and one of the competencies is self-regulated learning (SRL). Students are individuals who need to gain capacity development in the face of the challenges of increasingly complex times, and that is shown in the development of their SRL [6].

SRL defined as an active process of students conducted in an intentional way to determine the purpose of self-initiated learning in regulating learning time, determining learning needs, setting targets, monitors, and learning strategies, and conducting an evaluation process for what has been done without coercion from outside [7]. In line with this, [8] revealed 
that SRL requires students to become masters of their own learning, so it is necessary to be trained and developed. Research conducted by [9] states that there is a positive effect between learning independence and online academic success. The finding provides the understanding that student's SRL needs to be developed in the context of online learning. In general, SRL can be measured through nine indicators, which are: 1) learning initiatives; 2) diagnose learning needs; 3) set learning goals/targets; 4) monitor, organize, and control learning; 5) view difficulty as a challenge; 6) seek and utilize relevant sources; 7) choose and implement the right learning strategies; 8) evaluate learning processes and outcomes; and 9) self-concept ([10], [11]).

The implications of online learning as a result of pandemic can also be viewed from students' motivation during learning. This is corresponding with the statement from [12] that natural disasters are able to provide stimulus for students to optimize the use of technology more efficiently in learning. Through this pandemic, students are working to maximize the use of devices that support their lectures. Furthermore, [13] explained that motivation is one of five important components that should be considered for teachers in implementing online learning. Therefore, this research wants to refer the impact of pandemics on students' SRL based on their motivations, especially when faced with calculus learning. The focus of this research is on differential calculus course studied by first-year students.

In fact, the students in the first year, regardless of the selected course, still show a lack of knowledge and math skills needed to study mathematics courses at the university level, including calculus ([14], [15]). As the outbreak happened, both lecturers and students are required to develop calculus learning optimally by using the concept of online learning, including at Universitas Pelita Harapan (UPH) Faculty of Education. Students from UPH Faculty of Education have undergone lectures for differential calculus face-to-face between January and February 2020 as many as 8 meetings. However, the pandemic conditions that occurred in Indonesia in March 2020 caused students to be repatriated to their home regions and completed halfway through differential calculus courses online. This dynamic precisely led to the alleged influence of pandemics on students' SRL. We developed three research questions which were: 1) is there a significant difference of students' SLR from Mathematics and nonMathematics Education study programs based on their motivations; 2) is there an interaction between the study program and motivation in determining SRL; 3) do indicators analysis and open-ended questions in SRL instruments strengthen quantitative results obtained through this study?

\section{CALCULUS LEARNING IN THE PANDEMIC ERA}

Research conducted by [15] related to calculus learning affected by covid-19 shows a shift in the paradigm of students in looking at calculus in the context of this pandemic. The study was conducted by designing differential calculus exams based on consideration of the connection between the content of the course and the current event. The finding of his study is that the students' paradigm goes from viewing calculus as a routinely filled course to a course filled with countless applications in real life. This paradigm shift makes students interested in learning calculus even if it is implemented in online mode. This interest refers with the arguments of [16] where it shows the internal motivation arise in students' self. Motivation is viewed as one of the characteristics of learners that represents SRL ([9], [17]). This kind of motivation will lead to a greater level of success and encourage students to be more independent in mastering the materials that have been studied.

In addition, calculus learning in the pandemic era also encourages the utilization of digital technology as well as the discovery of creative solutions to practical problems, because in the context of online learning, students have opportunity to learn independently [18]. [19] presents several challenges in which one has to do with how lecturers are encouraged to think about how to motivate students in continuing calculus learning with separate distance condition. Another challenge in the study is based on an interesting report from a first-year student while studying calculus, which is how the student still wants his lecturer to provide writing materials even though the teaching is done by utilizing technology, in order to keep a situation when the lecturer teaches in the classroom. The report shows that there is a student's desire for intensity of students' engagement in organizing the learning process as well as adaptation into specific situations ([20], [21]), which is related to their SRL by referring to the preparation of learning objectives independently among these severe conditions.

As it was decided that students from UPH Faculty of Education were required to repatriate in March 2020, the differential calculus learning was carried out in online mode. The design used by lecturer is blended learning design, where students will experience two kinds of learning, both synchronous and asynchronous. In synchronous learning, lecturer meets face-to-face with students to discuss materials and issues in differential calculus. The need for virtual face-to-face meetings is because verbal discussion stimulates student involvement together when faced with calculus issues. This is supported by the argument from [22] through his study that building relationships in virtual classrooms is very useful to maintain students' motivation in learning. 
While in asynchronous learning, students are given exercises to be solved independently and if they encounter difficulties in the middle of the work, they can communicate with lecturers and peers through an accepted platform.

\section{RESEARCH METHODS}

This research was conducted at UPH Faculty of Education by taking samples of first-year students studying differential calculus courses as subjects affected by covid-19. The research sample is students of the class of 2019/2020, which is divided into two groups, the Mathematics Education study program as many as 44 students and the non-Mathematics Education study program as many as 29 students, in this case students from Physics Education and Chemical Education study program. This research uses Likert scale questionnaire of SRL as the instrument which contains 30 positive and negative questions spread into nine indicators and also open-ended questions that can be filled descriptively by students. Before analysing SRL, the two groups of students were divided into categories of high motivation and low motivation. The classification was carried out through Likert scale of motivational questionnaire, to then be divided normatively [23] with the procedure below:

$$
\begin{array}{ll}
\text { Low } & : \quad X<(\bar{x}-s) \\
\text { High } & :(\bar{x}+s) \leq X
\end{array}
$$

According to the classification, it is obtained that there are five students considered as low category and also high category from Mathematics Education. The number of students from non-Mathematics Education group are also five students both considered as low and high category based on classification mentioned. The research methods use mixed methods, where the analysis of findings is carried out quantitatively and qualitatively to provide more accurate and representative results [24]. Quantitative data analysis was conducted using a two-way Anova test to obtain the main effect as well as the interaction effect between the first-year student based on study program and their motivation related to SRL. Qualitative data analysis was conducted descriptively referred to the students' responses in the open-ended question on the instrument of SRL. The findings of this research will also be reviewed and linked into several related studies.

\section{RESULTS AND DISCUSSIONS}

Before doing statistical analysis, students from the study program of Mathematics Education and nonMathematics Education were first divided into high motivation and low motivation category. The division was done normatively [23] and obtained a spread of research samples presented in Table 1, in which each category, there were five students.

Table 1. Spread of Research Samples

\begin{tabular}{|l|c|c|}
\hline \multirow{2}{*}{ Motivation } & \multicolumn{2}{|c|}{ Study program } \\
\cline { 2 - 3 } & $\begin{array}{c}\text { Mathematics } \\
\text { Education }\end{array}$ & $\begin{array}{c}\text { Non-Mathematics } \\
\text { Education }\end{array}$ \\
\hline $\begin{array}{l}\text { High } \\
\text { motivation }\end{array}$ & 5 students & 5 students \\
\hline $\begin{array}{l}\text { Low } \\
\text { motivation }\end{array}$ & 5 students & 5 students \\
\hline
\end{tabular}

Data was taken through the filling of SRL instruments by both groups of students in each motivation category. Furthermore, data in the form of SRL scores were statistically analyzed with SPSS 16.0 using the two-way Anova test, by first conducting normality test and homogeneity test. The normality test was conducted using Kolmogorov-Smirnov, and obtained results in Table 2, where the value of Sig. > 0.05 which means that SRL scores come from a normal distributed population.

Table 2. Kolmogorov-Smirnov Normality Test

\begin{tabular}{|l|c|c|}
\hline \multicolumn{1}{|c|}{ Study program } & Sig. & Significance \\
\hline $\begin{array}{l}\text { Mathematics } \\
\text { Education }\end{array}$ & 0,722 & Normal distributed \\
\hline $\begin{array}{l}\text { Non-Mathematics } \\
\text { Education }\end{array}$ & 0,994 & Normal distributed \\
\hline
\end{tabular}

Homogeneity test was conducted using Levene's Test and obtained a Sig value $0.069>0.05$ indicating that data variance is homogeneous. Since the normality and homogeneity tests are met, the hypothesis test continues using the two-way Anova test. The results in Table 3 indicate that in terms of study program, the value of Sig. > 0.05 which means there is no difference in SRL between students in Mathematics Education and non-Mathematics Education study programs based on their motivation.

Table 3. Anova Two-Way Test

\begin{tabular}{|l|c|c|}
\hline \multicolumn{1}{|c|}{ Variance Source } & Sig. & Conclusion \\
\hline Study program & 0,488 & Insignificant \\
\hline Motivation & 0,001 & - \\
\hline $\begin{array}{l}\text { Study } \\
\text { program*Motivation }\end{array}$ & 0,452 & Insignificant \\
\hline
\end{tabular}


In terms of the interaction between study programs and students' motivation towards SRL, the results in Table 3 show Sig. score $>0.05$ which means that there is no interaction between the study program and motivation in determining the students' SRL.

In addition to statistical test results, there is also explanation of results related to the SRL indicators in each student category. For the Mathematics Education study program category, from nine indicators of SRL, students in the high motivation group reached $77.5 \%$ on indicator on the evaluation of the process and the results of the study. Based on the question item on the indicator, it is known that the students attempted to find the cause of the failure after facing the test by consulting their peers. In the low motivation Mathematics Education study program students' group, the highest percentage of $73.75 \%$ was achieved by indicators on viewing difficulty as a challenge in learning. Based on the question items on the indicator, it is known that students tend to feel anxious when given difficult problems and feel frustrated when failing to resolve them. However, students still have an effort in solving these difficult problems and believe that they are able to complete differential calculus courses online.

For the category of non-Mathematics Education courses, out of nine indicators of SRL, students in the high motivation group reached $78.33 \%$ on indicators on the diagnosis of learning needs. Based on the question point on the indicator, it is known that students are trying to provide additional time outside of online learning to learn difficult differential calculus problems independently. In the low motivation of nonMathematics Education study program students' group, the highest percentage of $73.33 \%$ was achieved by indicators on the diagnosis of learning needs. Students have become aware of the need to set time beyond online calculus learning related to working on difficult problems.

Through statistical exposure and studies of SRL indicators, it can be shown that learning differential calculus online makes students feel the need to improve their learning independence. Statistical result that is showing no difference in SRL between students in Mathematics Education and non-Mathematics Education study programs indicate that they consider SRL as an important factor to be developed in calculus learning online. This is corresponding with the argument put forward by [25] that SRL is an essential factor for students in an online learning environment, where student autonomy is at a high level and teacher attendance rates are at a low level.

In addition, statistical results also showed no interaction between study program and motivation in determining SRL. These results show that students in high-motivation and low-motivation groups from both Education and non-Mathematics Education study program understand SRL as vital and should be developed during online learning. Research from [26] concluded that online learning provides the potential to motivate students who foster SRL in their learning. Another study conducted by [27] stated that motivation plays a role in providing opportunities for students to find the right strategy when faced with a learning challenge. Due to pandemic that requires students to undergo calculus learning online, this situation raises student initiatives to be skilled in finding learning strategies that allow them to understand the concepts given and evaluate the learning process for the results obtained.

The SRL instrument also contains six open-ended questions. Through the questions, a summary of the results of each group is shown as follows:

\subsection{Question 1: What are the obstacles you face when learning Calculus online?}

In the Mathematics Education study program, highly motivated students explain the obstacles faced are network stability problems in the home region that allow student connections to be often disconnected during the online learning process. Another obstacle is the effectiveness of discussions with peers online that are no better than face-to-face discussions. It is because calculus learning contains of complex problems that should make room for students to engage in discussions. Meanwhile, low-motivated students also face obstacle of unstable networks during the learning process. In addition, students also find it difficult to understand the calculus content taught when listening through video recordings of teaching from lecturer. Students need repetition in listening to these explanations in order to understand the essence of being taught. These obstacles make students feel the need to search for other sources relevant to the topic of discussion, either through YouTube or browsing on Google.

In non-Mathematics Education study program, highly motivated students present obstacles that are related to direct communication with lecturers and peers. Students are in desperate need of face-to-face conditions when faced with difficult problems and do not find the solutions. Students acknowledge that the discussion process can be done online, but that it is considered less effective by them. This condition makes students feel more likely to find other resources to solve the problem than to ask lecturers and peers. Meanwhile, low-motivated students also present the same obstacles that are difficult to express the difficulties faced through typing. Even students take a long time in the process of writing a solution process about calculus to be shared with peers who need it. 


\subsection{Question 2: Is the role of the support system sufficient to assist you in undergoing Calculus learning online?}

In the Mathematics Education study program, highly motivated students explain that the role of lecturers, tutors, and peers as a support system is very helpful for students in the process of learning calculus online. Students feel helped by the explanations presented when faced with difficult problems that cannot be solved individually. Nevertheless, students feel the need to find other relevant resources when dealing with calculus learning online. Low-motivated students also revealed that the role of the support system is very impactful. In fact, students not only find support systems that are limited to peers on the same campus, but also peers on different campuses who are also studying calculus online.

In the non-Mathematics Education study program, highly motivated students revealed that there was a role of the support system during the discussion of the problems but felt less effective. It is because the explanation given by the support system through online media makes it difficult for students to understand the purpose being delivered. Nevertheless, students still feel able to complete calculus courses online through the help of the existing support system. Furthermore, lowmotivated students also claim that help from the support system is strongly felt. Through the provision of interactive videos created by tutors, making students understand the calculus concepts. The dominant support system felt by students is the role of peers. In fact, students also get help in the discussion of the problems through peers from the Mathematics Education study program.

\subsection{Question 3: What is the significant difference you feel between learning Calculus face-to-face and online?}

In the Mathematics Education study program, highly motivated students revealed that the significant difference felt was the atmosphere of learning, from the previous one face-to-face to online virtual face-to-face. This kind of learning atmosphere has an impact on the way teaching by lecturers as well as learning activities that occur. This transition causes students to be challenged to adapt to calculus learning online. Students with low motivation tend to feel the difference in learning atmosphere related to the discussion of the problems that are intertwined in the calculus course. Online learning makes students unable to ask peers directly as they are having difficulties. Students are also unable to ask directly when there is an explanation from the lecturer or video footage that is poorly understood. Lecturers and peers certainly need time to respond to questions from students about the problems faced, so students feel the need to find other resources while waiting for a response from lecturers and peers.

In non-Mathematics Education courses, highly motivated students revealed that it is more difficult to follow calculus learning online than face-to-face, because ongoing discussions are also sometimes difficult to understand regarding network stability, so students need more time to understand the discussions that are intertwined. This certainly makes students must set extra time of learning discussion outside of lectures, as well as impact on the acceptance of the concepts taught. In addition, it is also shown that online calculus learning makes students have to strive in understanding concepts independently. Low-motivated students explain that question and answer activities make a significant difference between face-to-face and online. Students prefer face-to-face learning because the Q \& A process can occur directly and provide a targeted understanding.

\subsection{Question 4: Have you done your best during calculus study?}

In the Mathematics Education study program, students with high motivation explain the best form of effort is to study every teaching material given optimally, be it in the PowerPoints form or video recordings of learning. Another effort is to maximize the work of differential calculus related problems and also the implementation of discussions involving support systems. Low-motivated students state that they have not done their best during calculus learning. This is indicated by the student's statement that there is still a tendency to study calculus only at the time the test or quiz will be conducted. In addition, there is a student self-concept factor states that there is still a sense of inferiority when seeing other peers actively involved during the discussion process. This psychological condition causes students being less active in discussions.

In non-Mathematics Education study program, there are differences in responses from highly motivated students. There are students who feel they have done their best by setting the study time optimally, studying not only when the test or quiz will be conducted, and seeking help from the support system if they find difficulty in solving calculus problems. However, there are also students who feel they have not done their best. It is shown from the student's response to avoiding the work of calculus problems that are difficult to work with. Another response, students also have doubts that the efforts made hard will produce maximum results, so this condition makes the students do not give their best efforts. For low-motivated students, there are also differences in responses to these questions. There are students who feel they have done their best by trying to work on every calculus problem personally. However, if 
the students find difficulty during the process, then they will ask their peers. But there are also students who feel they have not done their best in calculus learning online. It is demonstrated by statements from students that they do not make good use of time to re-study calculus contents outside of online lecture hours

\subsection{Question 5: What needs to be improved from how you learn during calculus course?}

In the Mathematics Education study program, highly motivated students realize that online learning is very susceptible to the laziness that arises. Therefore, students feel the need to improve learning styles that are more focused on setting study time outside of lecture hours, increasing the intensity of discussions with peers when discussing questions, and completing material notes from other sources relevant to the topic of learning. Students with low motivation are more likely to make improvements in the quality of study before online classes are implemented. Students feel the need to repeat the learning materials before the class meeting takes place and allocate time outside class hours to learn differential calculus. Besides, students also feel the need to improve accuracy by increasing the intensity of doing on various calculus problems.

In non-Mathematics Education courses, highly motivated students feel the need to improve time management in maximizing understanding of concepts contained in differential calculus. Students need to provide additional time at home to repeat the material that has been studied and work on the problems given by lecturers or from other relevant sources. Lowmotivated students also feel the need to improve time management effectively in order to make calculus course to be better understood.

\subsection{Question 6: Mention your commitment to the next Calculus course.}

In the Mathematics Education study program, differential calculus courses become prerequisite courses to participate in integral calculus courses and multivariate calculus courses in the next semester. Highly motivated students realize that calculus courses contain various problems and are intertwined with the concept of calculus that has been studied. It makes students feel the need to commit continuously to the intensity of the workmanship of the problems in a varied way. Students are encouraged to focus not only on the problems given by lecturers, but also to increase their initiative in finding related problems through other sources. All this certainly requires effective time management to be able to materialize. In addition, students are also committed to form a group as a community to discuss difficult calculus problems. Lowmotivated students feel the need to commit to self- concept, which is to increase optimism that students are able to understand and master the courses. This is materialized through the management of study time as well as the setting of learning targets achieved in calculus courses.

In non-Mathematics Education courses, students will get courses in Physics Mathematics and Chemistry Mathematics, where both courses are loaded with the need for calculus in problem solving. Highly motivated students are committed to not only relying on the contents delivered by lecturers, but also broadening their horizons through other sources. Students also recognize the importance of allocating time to repeat the material and make a summary as a commitment to be implemented on advanced calculus courses. Lowmotivated students are committed to devise more effective learning strategies and try not to focus too much on less rewarding activities. Besides, the commitment on optimizing the support system to discuss is also an important point put forward by students with low motivation.

Based on the student response of each open-ended question on the instrument of SRL, it can be summarized that online calculus learning motivates students to set learning time outside of lecture hours and also increase the intensity of students in communicating and discussing with peers about the difficulties faced when working on problems. In addition, students are also encouraged to utilize a variety of relevant sources beyond the materials provided by lecturers in strengthening knowledge of differential calculus. Research conducted by [28] translates all such activities as a form of self-arrangement conducted by students to achieve their learning goals in an online-based learning environment. The study conducted by Delen, Liew, \& Wison [29] provides the finding that a learning environment based on synchronous and asynchronous activity as part of online learning strongly supports students to seek additional resources and conduct selfevaluation to the maximum in achieving the results. It means that the atmosphere that builds up in online calculus learning motivates students to see difficulty as a challenge to be faced by utilizing all existing support systems.

\section{CONCLUSION}

Based on statistically test results, it was found that there was no difference in SRL between students of the Mathematics Education and non-Mathematics Education courses according to their motivations regarding differential calculus learning online. Moreover, there is no interaction effect between study programs and motivation on students' SRL. The results of these statistics are further analysed by conducting a 
descriptive study of the indicators of SRL and also open-ended questions contained in the instruments.

Through quantitative and qualitative reviews, it is concluded that students from both types of study programs and motivational groups view SRL as essential and need to be developed in studying differential calculus online. The students, both from high and low motivation groups, who are from Mathematics education and non-Mathematics education study programs state that in the context of online calculus learning, students need to organize additional time outside the classroom, increase the intensity of discussions with peers as a support system, utilize other learning resources relevant to the topic of learning, and need to practice evaluating and arranging learning targets for the goal to be optimally.

In this pandemic era, SRL is a factor highlighted as something that needs to be trained and developed during the online learning that allows it to be done synchronously or asynchronously. For a further research, SRL can be analysed in its development on other mathematics topics or other subjects. Researchers are able to analyse more about indicators on SRL in relation to online learning, so that treatment can be implemented to optimize indicators that are poorly achieved. Efforts in optimizing SRL can be done by applying learning methods that focus on extracting ideas and creativity of students, or utilizing online platforms to create gamification, so that the learning process in the pandemic era does not become a burden but gives encouragement and motivation to be more independent and skilled in the learning process.

\section{REFERENCES}

[1] R. Badjeber, Kemandirian belajar mahasiswa Tadris Matematika FTIK IAIN Palu selama pembelajaran daring, Jurnal Pembelajaran Matematika dan Sains 1(1) (2020) 1-9. [Online] Available: http://jurnalkoordinat.org/index.php/ koordinat/article/view/1/1

[2] V. Singh, A. Thurman, How many ways can we define online learning? A systematic literature review of definitions of online learning (19882018), American Journal of Distance Education 33(4) (2019) 289-306. DOI: https://doi.org/10.1080/08923647.2019.1663082

[3] S. Dhawan, Online Learning: A panacea in the time of covid-19 crisis, Journal of Educational Technology Systems 49(1) (2020 ) 5-22. DOI: https://doi.org/10.1177/0047239520934018

[4] E. Liguori E, C. Winkler, From offline to online: challenges and opportunities for entrepreneurship education following the covid-19 pandemic, Entrepreneurship Education and Pedagogy 3(4)
(2020) 346-351. DOI: https://doi.org/10.1177/2515127420916738

[5] F. Nursyahidah, I.U. Albab, Identifikasi kemampuan berpikir kritis matematis mahasiswa berkemampuan pemecahan masalah level rendah dalam pembelajaran kalkulus integral berbasis problem based learning, Jurnal Elemen 4(1) (2018) 34-49. DOI: https://doi.org/10.29408/jel.v4i1.513

[6] T. Shuy, TEAL Center Fact Sheet No. 3: SelfRegulated Learning, in TEAL: Teaching Excellence in Adult Literacy, 2010. [Online] Available: https://lincs.ed.gov/sites/default/files/3_ TEAL_Self\%20Reg\%20Learning.pdf

[7] B. J. Zimmerman, Self-regulated learning: Theories, measures, and outcomes, in International Encyclopedia of the Social \& Behavioral Sciences, 2015, pp 541-546. DOI: doi:10.1016/B978-0-08097086-8.26060-1

[8] S. P. Tull, N. Dabner, K. A. Arthur, Social media and e-learning in response to seismic events: Resilient practices, Journal of Open, Flexible and Distance Learning 21(1) (2017) 63-76. [Online] Available:

http://www.jofdl.nz/index.php/JOFDL/article/view/ 405/261

[9] A. Martin, How to Optimise Online Learning in the Age of Coronavirus. [Online] Available: https://newsroom.unsw.edu.au/news/socialaffairs/how-optimise-online-learning-agecoronavirus.

[10] WHO, Emergency: Coronavirus disease (covid-19) pandemic, 2020. [Online] Available: https://www.who.int/emergencies/diseases/novelcoronavirus-2019/

[11] K. Saxe, L Braddy, Common Vision for Undergraduate Mathematical Sciences Programs in 2025, The Mathematical Association of America, 2020.

[12] V. Jungic, making calculus relevant: final exam in the time of covid-19, International Journal of Mathematical Education in Science and Technology (2020) 1-13. DOI: https://doi.org/10.1080/0020739x.2020.1775903

[13] J. J. A. Denissen, N. R. Zarrett, J. S. Eccles, i like to do it, i'm able, and i know $\mathrm{i}$ am: longitudinal couplings between domain-specific achievement, self-concept, and interest, Child Development 78(2) (2007) 430-447. DOI: https://doi.org/10.1111/j.1467-8624.2007.01007.x

[14] N. G. A. Eka, G. S. Houghty, Juniarta. Motivation and self-learning readiness of blended learning in research and statistics course for undergraduate nursing students, JOHME: Journal of Holistic Mathematics Education 3(1) (2019) 32-43. DOI: http://dx.doi.org/10.19166/johme.v3i1.1919 
[15] A. Bakker, D. Wagner, Pandemic: Lessons for today and tomorrow? Educational Studies in Mathematics 104(1) (2020) 1-4. DOI: https://doi.org/10.1007/s10649-020-09946-3

[16] A. Wigfield, J. S. Eccles, D. M. Iver, D. A. Reuman, C. Midgley, Transitions during early adolescence: Changes in children's domain-specific selfperceptions and general self-esteem across the transition to junior high school, Developmental Psychology 27(4) (1991) 552-565. DOI: https://doi.org/10.1037/0012-1649.27.4.552

[17] S. Kulakow. Academic self-concept and achievement motivation among adolescent students in different learning environments: Does competence-support matter? Learning and Motivation vol 70 (2020) 1-15. DOI: https://doi.org/10.1016/j.lmot.2020.101632

[18] N. Joss, The Mathematical Language of Change: Teaching Calculus During the Pandemic, 2020, [Online] Available: https://www.thecollegianur.com/article/2020/08/ teaching-calculus-during-the-pandemic.

[19] S. Azwar, Penyusunan Skala Psikologi, Pustaka Belajar, 2013.

[20] J. W. Creswell, Research Design: Qualitative, Quantitative, and Mixed Methods Approaches, Sage Publications, 2014.

[21] R. Azevedo, A. F. Hadwin, Scaffolding Selfregulated Learning and Metacognition-Implications for the Design of Computer-based Scaffolds, Instructional Science 33(5) (2005) 367-379. DOI: https://doi.org/10.1007/s11251-005-1272-9

[22] B. Kramarski, T. Revach. The challenge of selfregulated learning in mathematics teachers' professional training, Educational Studies in Mathematics 72(3) (2009) 379-399. DOI: https://doi.org/10.1007/s10649-009-9204-2

[23] H. Neber, J. He, B. Liu, N. Schofield, Chinese highschool students in physics classroom as active, selfregulated learners: Cognitive, motivational and environmental aspects, International Journal of Science and Mathematics Education 6(4) (2008) 769-788. DOI: https://doi.org/10.1007/s10763-0079110-y

[24] T. Lehmann, I. Hähnlein, D. Ifenthaler, Cognitive, metacognitive and motivational perspectives on preflection in self-regulated online learning, Computers in Human Behavior vol 32 (2014), 313323. DOI: https://doi.org/10.1016/j.chb.2013.07.051

[25] A. Devolder, J. Van Braak, J. Tondeur, Supporting self-regulated learning in computer-based learning environments: systematic review of effects of scaffolding in the domain of science education, Journal of Computer Assisted Learning 28(6) (2012) 557-573. DOI: https://doi.org/10.1111/j.13652729.2011.00476.x

[26] A. R. Artino, J. M. Stephens, Academic motivation and self-regulation: A comparative analysis of undergraduate and graduate students learning online, The Internet and Higher Education 12(3-4) (2009), 146-151. DOI: https://doi.org/10.1016/j.iheduc.2009.02.001

[27] S. Lee, H. Shin, The influence of middle and high school students' learning motivation, academic effort and self-regulated learning strategies on english academic achievement, Secondary Education Research 60(4) (2012) 1045-1077. DOI: https://doi.org/10.25152/ser.2012.60.4.1045

[28] N. Dabbagh, A. Kitsantas, Supporting selfregulation in student-centered web-based learning environments, International Journal on E-Learning 3(1) (2004) 40-47.

[29] J. Wong, M. Baars, D. Davis, T. Van Der Zee, G. Jan Houben, F. Paas, Supporting Self-Regulated Learning in Online Learning Environments and MOOCs: A Systematic Review, International Journal of Human-Computer Interaction 35(5) (2019) 356-373. DOI: https://doi.org/10.1080/10447318.2018.1543084 